\title{
A Nemzeti Casino
}

\section{A kulturális örökség}

Az utóbbi időben - fokozatos alakulás következtében - a kulturális örökség kulcsfogalommá nőtte ki magát a nyugat-európai kultúrpolitikában, és mindennapi életünk részévé vált. A fogalom körül tudományos viták alakultak ki az 1980-as évek elejétől fogva. Hazánkban kicsit megkésve, a Nemzeti Kulturális Örökség Minisztériumának létrejöttével, 1998-tól jutott a nyugat-európaihoz hasonló szerephez a politikai párbeszédben. Az örökség fogalma köré a 2000-es évek kezdetén már konferenciák szerveződtek. ${ }^{1}$

Az örökség-fogalom nemzeti szintü értelmezése a francia forradalom hatására alakult ki, a nemzeti örökség fogalmát Édouard Pommier hozta létre 1790ben. Az 1960-as évekig a történeti mủemlék a meghatározó, a régiség, a kor a döntő szempont. Ekkor jelentésbővülésen ment át a fogalom, megjelent az építészeti örökség, majd az 1970-es években a kulturális örökség a kollektív emlékezettel egészült ki, ezzel is gyarapítva a megőrzésre szánt csoportok körét.

Franciaországban az 1979-es levéltári törvény említi először az örökséget. Az Európa Tanács 1985-ös kongresszusa határolja körül a fogalmat, de a közös európai örökség fogalma már 1949-ben meghatározásra került. 1994-ben az Európai Helyi és Regionális Tevékenységek Kongresszusa meghatározta a helyi és regionális kulturális örökség körülhatárolásának, megörzésének az alapelveit. ${ }^{2}$

Mindezeknek és az UNESCO Világörökségi Központjának köszönhető, hogy „a kulturális örökség a legkisebb falusi közösségektöl az emberiség egészéig szervező elvvé vált, mely alkalmasnak tünik arra, hogy reprezentálja e közösségek identitástudatát."

„A kulturális örökség a közösség számára fontos jelentéssel bíró tárgyak vagy tárgyakkal kifejezett immateriális dolgok készlete." ${ }^{\prime 4}$ A tárgyakat a kijelölt intézmények gyüjtik, feltárják, őrzik és a közösség számára hozzáférhetővé teszik. Ezáltal a tárgyak kibővülnek a feldolgozó értelmezésével, eggyé válnak az emlékezettel, az örökséget és az emlékezetet együtt kell értelmezni. Mindkét fogalom az identitás része, ezt meg kell keresni, őrizni és ismét felfedezni.

A két fogalom összekapcsolódik egy harmadikkal, a történelemmel, de az örökség nem azonos sem a múlttal, sem a történelemmel. A múltnak csak egy

${ }^{1}$ Sonkoly Gábor: A kulturális örökség fogalmának értelmezései és alkalmazási szintjei. = Regio, 11. évf. 2000. 4. sz. 45 p.

${ }^{2}$ Erdösi Péter - Sonkoly Gábor: A kultúra melankóliája. A kulturális örökség fogalmának megjelenése. = Valóság, 48. évf. 2005. 6. sz. 74-75 p.

${ }^{3} \mathrm{im}$. Sonkoly G. 46 p.

${ }^{4}$ im. Sonkoly G. 47 p. 
válogatott és értelmezett része válhat a történelem részévé. Az örökség viszont az emlékezetbe vésett múlt átalakításából jön létre.

A kulturális örökség több szinten valósulhat meg, jelen van helyi, regionális, nemzeti és nemzetek fölötti szinten is. A különböző szinteken másképp valósul meg az örökség, és mást értenek alatta: a kulturális örökség nemzeti szinten nemzeti örökséget jelent, az Európai Unión belül a sokszínűséget hirdetik, melyre egy példa lehet a világörökségi helyszínek listája. Minden esetben meg kell határozni, hogy egy objektum mitől válik érdemessé arra, hogy ezt egy nagyobb közösség magáénak vallja.

Egy ilyen helyi vagy nemzeti kulturális örökségnek tekinthető a Nemzeti Casino.

\section{Nemzeti Casino}

Széchenyi István 1827-ben alapította meg a Nemzeti Casino-t (= NC), mely 1830-ig Pesti Casino néven müködött. Széchenyi az ünnepélyes megnyitón vázolta az egyesület célját, vagyis „hogy hazánkban is legyen egy olyan megkülönböztetett díszes összegyülekezőhely, melyen főbb és előkelőbb és jobb nevelésủek, eszes, értelmes férjfiak, a társasági rendnek mindenik osztályából egymással vagy barátságos beszélgetés végett találkozzanak vagy többféle politikai ujságokat s hasznos gazdasági, tudományos, mủvészi hónapos-írásokat olvashassanak, magukat pedig üres óráikban illendően mulathassák".5

Már ekkor 175 részvényese volt az egyesületnek. Bizottságot állítottak fel az alapszabályok kidolgozására és az egyesület ügyeinek intézésére.

Az NC szük körủ országgyülésként is müködött, az ülések után itt folytatódott a döntések megvitatása, mindez ellentétes volt az alapítók céljaival. A politizálás ellen többször is fellépett az NC igazgatósága. Ezt igazolja például Kossuth Lajos esete is, aki 1836-ban kérte felvételét az egyesületbe: „a nemzeti casino tömérdek hírlapot hordatott és szép könyvtára volt, szerettem volna hasznukat vehetni". Széchenyi személyesen kérte meg az új tagjelöltet, hogy vonja vissza a kérelmét, félt, hogy a bécsi udvar politikai lépésnek vélné. Kossuth visszavonult: „,..itt ön [Széchenyi] a házi gazda; én annak nézem, s nem szokásom oda tolakodni, ahol tudom, hogy nem szívesen látnak."

A Nemzeti Casino minden évben kiadta az aktuális alapszabályait, házirendjét és tagjainak a névsorát. Az NC nem exkluzív klubként jött létre. Köreibe tartoztak tisztviselők, táblabírák, ügyvédek, orvosok, tudósok, írók, kereskedők, gyógyszerészek. ${ }^{7}$ Szigorú szabályok vonatkoztak a kártyajátékra is. Amennyiben

${ }^{5}$ Ilk Mihály: A Nemzeti Casino százéves története: 1827-1926. Budapest, Franklin Nyomda. 1927. 8-9. p.

${ }^{6}$ Simon Zoltán: A reformkori magyar politikai nyilvánosság és a Nemzeti Kaszinó. $=$ Sic Itur Ad Astra, 12. évf. 2000. 3. sz. 38-40 p.

${ }^{7}$ im. Ilk M. 11 p. 
valamelyik tag nem törlesztette az adott határidőn belül a játékban felmerült tartozását, kizárhatták az egyesületből.

A Casino helyiségei, mint a társalgó, olvasóterem, játékterem és az étterem csak a kijelölt célokra voltak használhatók. A könyvtár dokumentumait - könyvek, folyóiratok, hírlapok, térképek, egyéb nyomtatványok - csak helyben lehetett használni, az olvasó- és a játékteremben tilos volt étkezni és csendben kellett lenni. Az éttermen kívül kizárólag este 10 óra után lehetett ételt felszolgálni. A helyiségek reggel 11 órától hajnali 5 óráig tartottak nyitva.

Gróf Széchenyi István végrendeletében a Casino-ra egy aranyserleget hagyott, és kérte, hogy „minden esztendőben tartassék ott egy részvényesi ebéd s akkor az én emlékezetemre üríttessék ki az említett serleg, mely az akkori borok leghelyesebbikével legyen meg- s megtöltve."

„A nemzeti Casino vagyona feloszthatatlan, és ahhoz se részvényesek, sem az egyletből kilépett tagok, sem azok örökösei, hagyományosai vagy engedményesei legkisebb jogot sem tarthatnak. Azon esetben, ha az egylet feloszlatása, emberi számítás szerint előre nem látható bármi rendkívüli okok vagy eseményeknél fogva, elkerülhetetlenül bekövetkeznék, összes vagyona, mint szintén feloszthatatlan alapítvány a magyar tudományos akadémia avagy az annak helyébe netán lépett hasonló jellegü magyar tudományos intézetre háramlik."”

\section{A Nemzeti Casino könyvtára}

1827-ben az NC megalapításakor Széchenyi felajánlotta 338 kötetes könyvtárát, ezzel megalapozta a gyüjteményt. A tagok ekkor még további 250 kötetet gyüjtöttek össze. ${ }^{10} 1829$-től a beszerzési keretet csak magyar müvekre lehetett fordítani. Az 1834-ben már 3000 müvet tartalmazó állomány többsége ennek ellenére idegen nyelvű művekből állt, köszönhetően a sok külföldi kötetet tartalmazó adománynak és hagyatéknak. ${ }^{11}$

A gyüjtemény magánjellegü könyvtárként jött létre, a tagok kizárólag helyben használhatták. Egy nagyterem, 3 szoba és egy olvasóterem szolgálta a könyvtár céljait. A nagyteremben a könyvállomány, a kisebb termekben a hírlapok sorakoztak. Több katalógus segítette az eligazodást: egy betủrendes cédulakatalógus (1873), egy szak szerinti cédulakatalógus (1873), egy index, melyben a könyvek és az új szerzemények szerepeltek betürendben és egy nyomtatott katalógus (1852). ${ }^{12}$

\footnotetext{
${ }^{8}$ im. Ilk M. 39-40. p.

${ }^{9}$ A nemzeti casino alapszabályai. 1895. 24 p.

${ }^{10}$ György Aladár: Magyarország köz- és magánkönyvtárai 1885-ben. 1886. 68 p.

${ }^{11} \mathrm{im}$. Simon Z. 42 p.

${ }^{12}$ Csontosi János: Emlékirat a Nemzeti Casino könyvtáráról. = Magyar Könyvszemle, 12. évf.
} 1887. 1-6. sz. 124 p. 


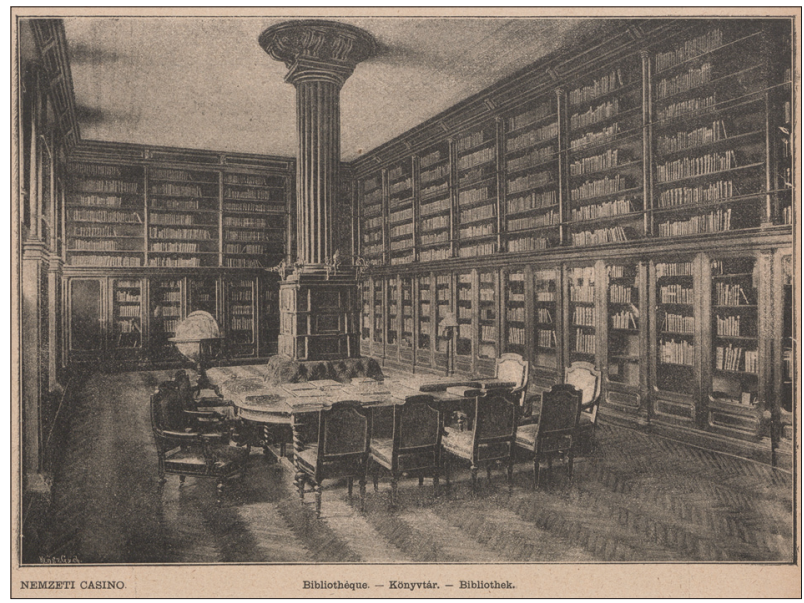

1. kép. A Nemzeti Casino könyvtára ${ }^{13}$

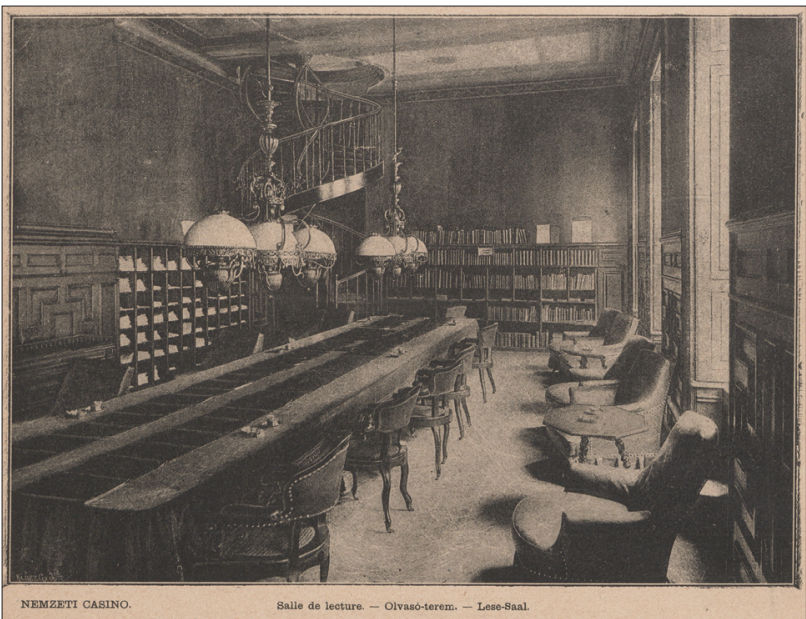

2. kép. A Nemzeti Casino olvasóterme ${ }^{14}$

A könyvtár főbb adományozói voltak gróf Dessewffy Aurél, Tasner Antal, Láng Ignácz, Weisz Bernát F., Szilágyi Ferenc, Török János. A megbízott könyvtárnokok nagy hangsúlyt fektettek a könyvtárra, „föntartása és kezelése a szakrendezés keresztülviteléig a könyvtártudomány és bibliographia igényeinek s az intézet traditióinak egyaránt megfelelt". ${ }^{15}$

${ }^{13}$ A kép forrása: http://ybl.bparchiv.hu/nemzeti-casino-konyvtar-klosz-gyorgy-fenykepe-nyoman (2016. október 16.)

${ }^{14}$ A kép forrása: http://ybl.bparchiv.hu/nemzeti-casino-olvaso-terem-klosz-gyorgy-fenykepenyoman (2016. október 16.)

${ }^{15}$ im. Csontosi J. 119 p. 


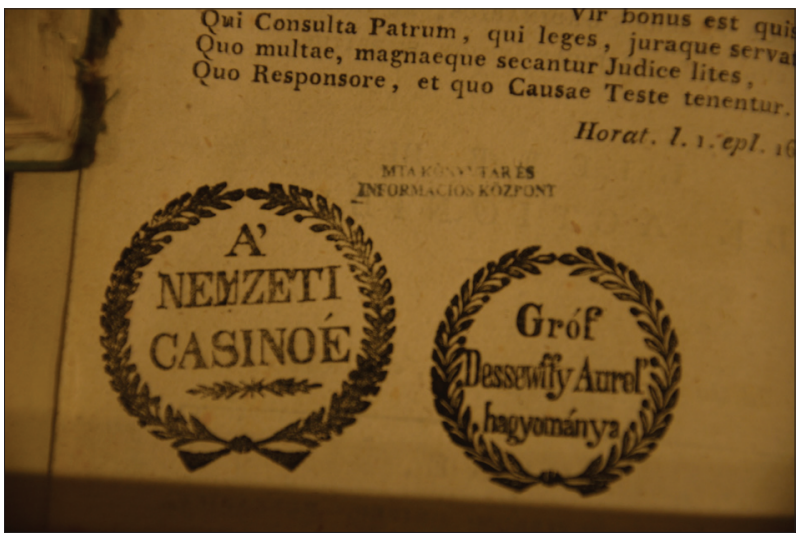

3. kép. Gróf Dessewffy Aurél pecsétje

A korabeli leírásokból megtudhatjuk, mit tartalmazott az állomány: „A könyvtár legnagyobb kontingensét a magyar irodalom termékei s a magyar történeti kútfők szolgáltatják. A könyvtár birja a m. t. akadémia s a Kisfaludy-társaság összes kiadványait, a magyar zeneiróknak legnagyobb részét s a magyar tudományos irodalomnak minden nevezetesebb termékét."16

1884-ben a helyben használók, 1800 tag, összesen 3210 kötetet olvastak. Az állományba tartozott 13 kézirat, két régi, 1711 előtti magyar nyomtatvány, 400 térkép, 1 földgömb, illetve egy régi festmény is. ${ }^{17}$

Az NC termeiben minden szaknál külön sorakoztak a magyar nyelven írt munkák, a Magyarországra vonatkozók és a külföldi irodalom termékei. A könyvtár osztályozási rendszere 1852-ben a következő volt: ${ }^{18}$

I.: Irodalomtörténet, Itészet (Mübírálat), Nyelvészet, Bibliográfia, Szótárak, Enciklopédiák;

II.: Klasszikusok, Szépirodalom, Müvészet, Régiségek;

III.: Filozófia, Nevelés, Iskolaügy, Vallás, Egyház, Mitológia;

IV.: Történelem, Életírás, Emlékiratok, Oklevéltan, Érmetan, Címertan, Genealógia;

V.: Földirat, Statisztika, Utazások, Helyrajzok, Népismertetés, Kalauzok;

VI.: Politika, Államtudomány, Közélet, Társadalom, Törvény- és jogtudomány, Büntetőügy;

VII.: Nemzetgazdaság, Pénzügy, Ipar, Kereskedelem, Közlekedés;

VIII.: Természettudományok, Orvostan, Baromorvoslat, Gazdaság, Földmüvelés, Állattenyésztés, Erdészet, Vadászat, Kertészet;

16 im. György A. 69. p.

${ }^{17} \mathrm{im}$. György A. 70. p.

${ }^{18}$ Pákh Albert [összeáll.]: Kalauz a’ Nemzeti Casino könyvtárához. Pesten, Trattner Nyomda. 1852. 259-313. p. 
IX.: Matematika, Csillagászat, Építészet, Kézmütan, Hadtudomány;

X.: Vegyesek.

Egy 1886-os jelentés szerint ez a „legrégibb és legtekintélyesebb ilynemü könyvtár az országban ... közkönyvtáraink közt is számot tesz.”19

\section{A feloszlatás}

A magyar belügyminiszter a 251.044/1945.IV./14 számú rendeletével feloszlatta az NC-t, mint ,az ország érdekeivel ellentétes müködést kifejtö jogi személy”-t. ${ }^{20}$ Ekkor a föváros megkezdte az egyesület vagyonának leltárba vételét és lefoglalását. Amint a Magyar Tudományos Akadémia (MTA) - mint az alapszabályok szerinti jogutód - tudomására jutott az eset, bejelentette igényét az örökségre, illetve jelezte együttmüködését és támogatását a kármentés folyamatában.

Az NC teljes vagyona ekkor:

a) két bombatalálatot kapott épület (Kossuth L. utca 5., Gellérthegy utca 5.)

b) ingó vagyon - tagok a háború elött vidékre mentették, többsége megsemmisült

c) NC iratai megsemmisültek a háborúban

d) könyvtár a romépületben

- 20.000-23.000 kötetet azonnal átszállítottak az Egyetemi Könyvtárba (1945. okt.), melyet 1947 júniusában továbbszállították az Akadémia épületébe

- a fennmaradó 6.000-10.000 kötet később került az Akadémia épületébe (1946. máj.)

- az értékesebb könyveket a háború előtt az Országház pincéjébe rejtették el, melyek ott elégtek

e) vadásztrófeák (Természettudományi Múzeumban örökletétként)

f) NC mutatói, osztálykatalógusai (jelenlegi lelőhelyük nem ismert)

A feloszlatást követő eseményekről részletes beszámoló áll rendelkezésre, de ugyanakkor a következő évtizedek történéseiről kevés az információ.

\section{Nemzeti Casino az Akadémia könyvtárában}

A könyvek kézbevétele hosszú évekig váratott magára. Az MTA könyvtárának éves jelentései időről időre említést tesznek az állományról, de mindig csak a könyvek rendezése kapcsán, a tételes feldolgozásra ez idáig még nem került sor. 1985-től rendszerezték a könyveket, eleinte könyvre és folyóiratra szétválogatva az anyagot, külön a magyar és az idegen nyelvüeket, majd szerzői betürend kialakítását kezdték meg. 1999-ben az MTA KIK Kézirattár és Régi Könyvek Gyüjteményének munkatársa, Mázi Béla egy rövid kéziratban foglalta össze az NC

${ }^{19}$ im. Csontosi. 118. p.

20 Ügyészi jelentés. 1945. MTA KIK Kézirattár és Régi Könyvek Gyüjteménye. RAL 234/1945. 
feloszlatásával kapcsolatos információkat. ${ }^{21} 2008$ körül újrarendezték az állományt, ekkor már az NC osztályszámai szerint.

Az állomány tényleges feldolgozása 2014 elején kezdődött meg. A köteteket a feladattal megbízott szakember letisztogatja, behasonlítja a korábbi NC művekkel, feldolgozza, digitalizálja a címoldalakat és a tartalomjegyzékeket, s ezeket csatolja a leírásokhoz, végül raktári jelzettel látja el.

Jelenleg a könyvtárban közel 17.700 NC-gyüjteményböl származó kötet található, és további 2.000 kötet van még a Magyar Nemzeti Múzeumban (= MNM). Feldolgozásuk megkezdése óta több mint 5.600 könyvrekord került be a könyvtár integrált könyvtári rendszerébe. A leírások a régi könyvek feldolgozási kritériumai szerint készülnek, figyelembe véve a könyvtár MARC 21-re épülö házi szabályzatát.

A rekordokban minden kötetnél jelöljük a kötés típusát, az összes kézírásos bejegyzést, pecséteket, bélyegzőket, fizikai hiányosságokat, sérüléseket.

Az eddig összesen elkészült 5684 rekordból 1759 idegen nyelvü mü leírása. A magyar nyelvủ osztályokba tartozó kiadványok már feldolgozásra kerültek. A külföldi könyvek jelentős hányada az eddigi feldolgozás tanúságai szerint német nyelvü volt, de akadt néhány francia, angol, latin és olasz is. A kötetek többsége a 19. században, illetve a 20. század elején jelent meg. A régi könyvek közül 790 darab 1850 elötti magyar (ebből 15 db 1800 előtti), és 6 darab 1800 előtti idegen nyelvü leírás készült.

Megtörtént a folyóiratok elkülönítése a könyvektöl, jelenleg összesen 5.774 folyóiratszám (449 cím) szerepel a rendszerben.

A munka során megtörtént a penészesnek tünő kiadványok leválogatása. Külső szakemberek megállapították, hogy nem élő penészről van szó, ezért fölöslegessé vált az elkülönítés. A hányatott sorsú állományban sok példány sérült, hiányos, keresztüllőtt, és néha még a lövedékek is a kötetben maradtak.

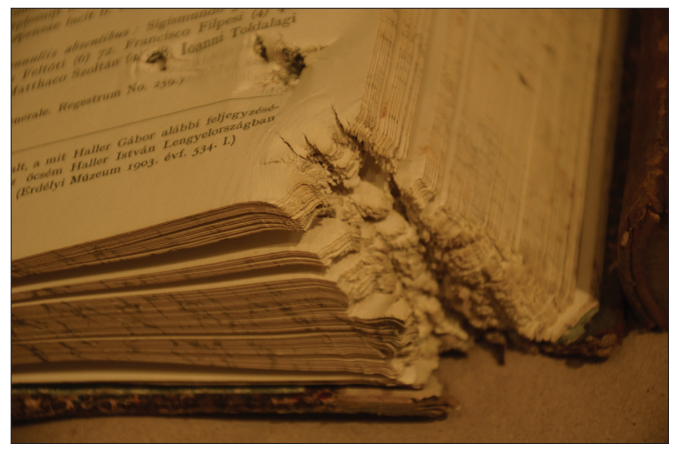

4. kép. Egy sérült kötet

${ }^{21}$ Mázi Béla: A Nemzeti Kaszinó könyvtára a Magyar Tudományos Akadémia Könyvtárában. Kézirat. Budapest, 1999. 
A kötetek többnyire félbőr vagy félvászon kötésủek, egységes stílusúak. A gerincen aranyozva legtöbbször a Nemzeti Casino, N. Casinoé vagy az N.C. szerepel. Minden könyvben megtalálható az NC exlibrise és legalább egy pecsét.

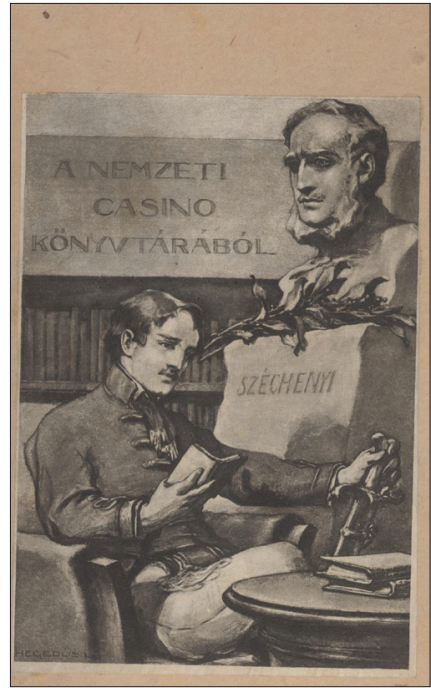

5. kép. Az NC exlibrise

Sokszor többféle pecsétet is tettek egy mübe, és előfordul, hogy minden fejezet végén található egy pecsét.
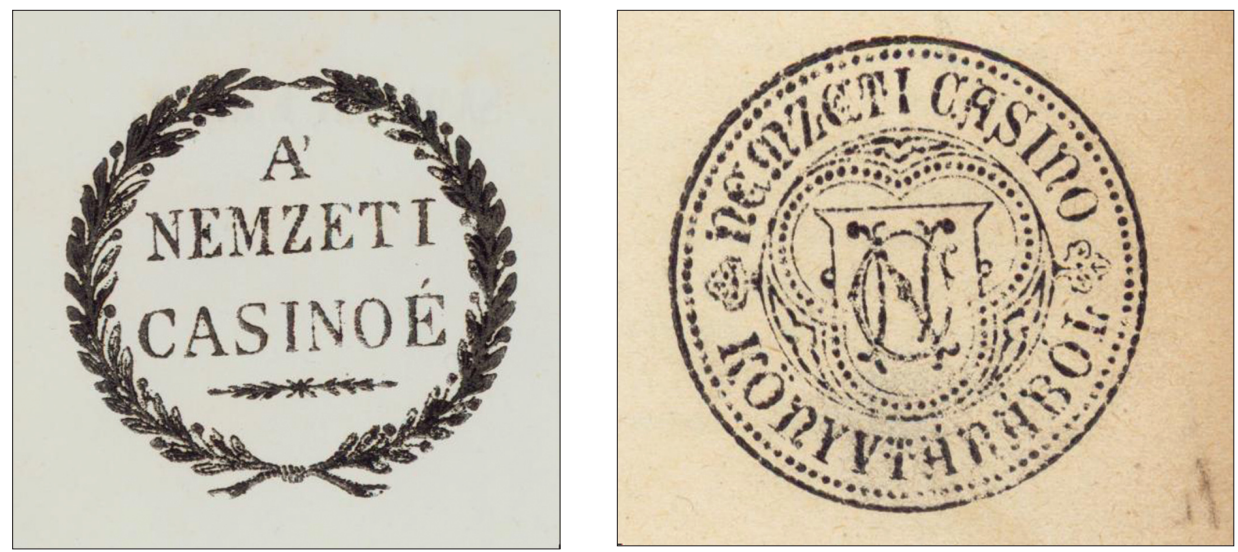

6-7. kép. Az NC két leggyakoribb pecsétje

A kötetek egy része azonos könyvkötő mühelyből került ki, ez kiderül a könyvek végén található szárazpecsétekből, melynek szövege: „Molnár Mihály ezelőtt Bóka L. könyvkötő Budapesten”. 


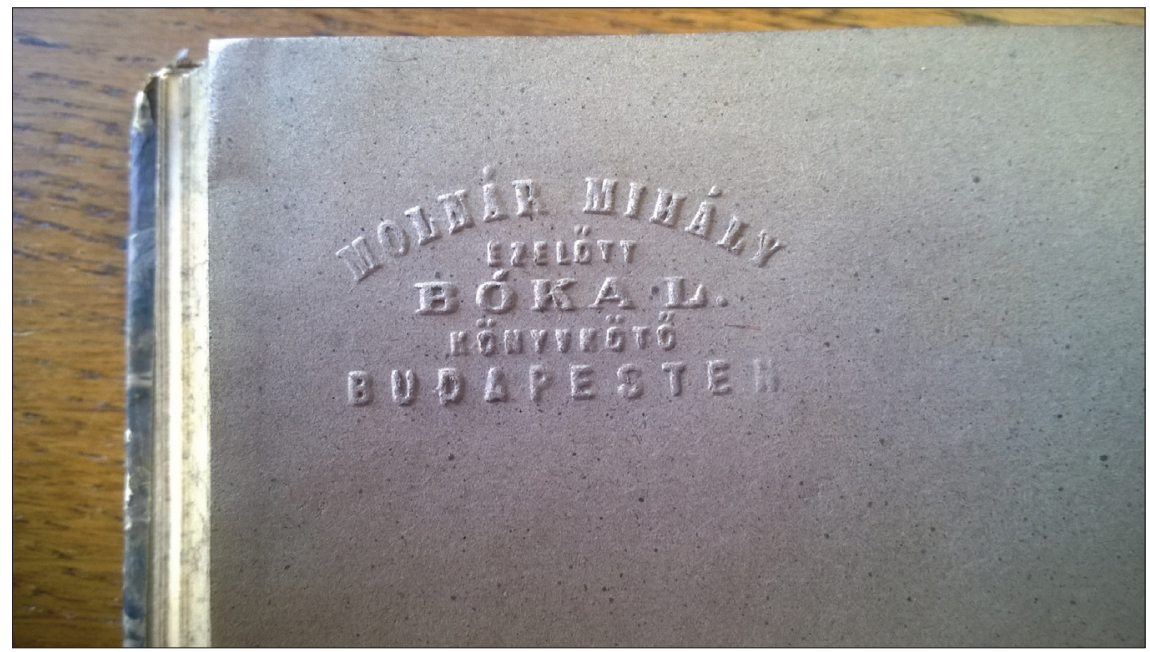

8. kép. A szárazpecsét

A könyvár inventáriumai még lappanganak. A feljegyzések szerint a feloszlatást követő költözéskor a romos épületből elszállították a következőket:22

- 1943-ig vezetett betürendes mutató a könyvtárhoz, 4 kötetben;

- az NC osztálykatalógusai 13 kötetben (két osztály katalógusa már ekkor hiányzott);

- az NC névkönyvei és az Idegenek könyve;

- továbbá más egyéb tárgyak.

Ezeket a katalógusokat még keressük. Az egyéb tárgyak között volt egy 1830as évekből származó földgömb, illetve hét ${ }^{23}$ afrikai és magyar vadásztrófea. 1947. augusztus 1-jén a trófeákat a MTA Könyvtára átengedte örökletétként a Természettudományi Múzeumnak, a „tönkremenés veszélyétől való megóvás végett" ${ }^{24}$ Jelen kutatásunk során felvettük a kapcsolatot a Természettudományi Múzeummal, ahol tájékoztattak minket, hogy sajnálatos módon az 1956-os események során tüz ütött ki az épületükben, így sok mütárgy megsemmisült. A tételes keresés során viszont rátaláltak öt vadásztrófeára, melyek sértetlen állapotban jelenleg is az állományuk részét képezik.

Az NC tulajdonában voltak egyéb mütárgyak is (festmények, térképek, bútorok), ezek hollétéről ma még nincs információ. Minden valószínüség szerint egy részüket vidékre mentették, más részük a romépületben maradhatott, esetleg megsemmisült.

${ }^{22}$ Nyireo János: Pro memoria. 1946. MTA KIK Kézirattár és Régi Könyvek Gyűjteménye. K 829:282/1946.

${ }^{23}$ Egyes iratok 8 trófeát említenek.

${ }^{24}$ Melich János: [Levél az Elnök Urnak]. 1947. 


\section{Nemzeti Casino a Magyar Nemzeti Múzeumban}

A feldolgozás megkezdésével párhuzamosan kezdetét vette az NC történetének és fennmaradt iratainak kutatása is. Hamar előkerült néhány dokumentum, melyekből megtudtuk, hogy az Akadémiai Könyvtár 2001 kötet régi könyvet adott át a Magyar Nemzeti Múzeumnak 1991 augusztusában, egy Széchényi-emlékkiállítás céljára. A könyvek kiválasztásánál a múvek kötése és állapota játszott szerepet. A könyvek azóta is a Múzeum Széchényi-termében vannak kiállítva. (Széchényi Ferenc emlékére készült a kiállítás és a terem, ennek a részét képezi a fia hagyatéka.)

2015 kezdetén megtörtént ennek az állományrésznek a számbavétele is. A külön kezelt könyvek a folyóiratok megoszlásának számaránya 50-50\%.

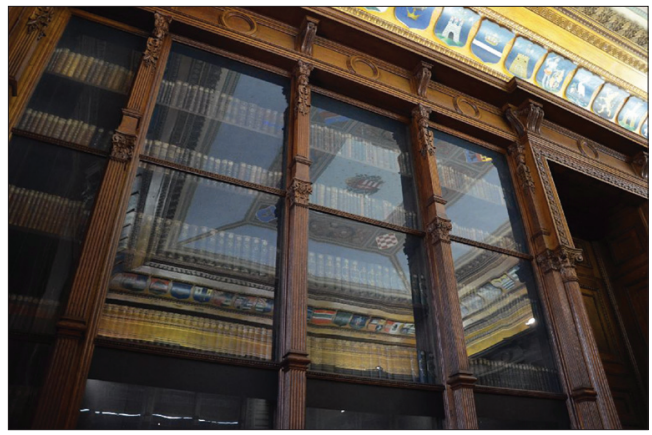

9. kép. A MNM Széchényi-terme

\section{További teendők}

Az utolsó állományadatok szerint a gyüjtemény 30.000-40.000 kötetből állt. Ebből jelenleg 20.000 nyomtatványt ismerünk. A hiányzó rész vagy háborús bombatalálatok következtében semmisült meg, vagy hollétéről ma még nincs adatunk, például magánszemélyekhez kerülhetett. Ezzel magyarázható például, hogy az utóbbi években egy-egy kötet felbukkant néhány antikvárium kínálatában.

Előzetes becslés szerint feldolgozásra vár még mintegy 6.000 kötet. A teljes állomány tényleges katalogizálási folyamata várhatóan két év alatt fejeződik be. A folyóiratok előzetes számbavétele már megtörtént, a továbbiakban szükséges az adatok pontosítása, kiegészítése, és összevetésük a törzsgyüjteményi állománnyal. Az állomány eddig feltárt történetéből látható, hogy milyen mértékben sérültek a dokumentumok, s közülük jelentős rész restaurálásra szorul.

A feldolgozás után kezdetét veheti a Nemzeti Casino könyveinek statisztikai áttekintése, mely átfogó képet adhat az állomány pontos összetételéről. Az egyesület történetének további kutatása még várat magára, emellett újabb hiánypótló információk remélhetők a vidéki és erdélyi kaszinók müködésének megismeréséből.

A nagyközönségnek egy kiállítással tervezi a könyvtár bemutatni a Casino történetét, örökségét, ritkaságait és különlegességeit. 


\section{Rezümé}

A Nemzeti Casino egyesületet Széchenyi István alapította 1827-ben. Közel 120 éves fennállása során szerves részét képezte a magyar közéletnek és kultúrának. Tervszerủen gyarapított és rendszerezett könyvtára kiemelkedett az ország közkönyvtárai közül, mind tartalmi, mind mennyiségi szempontból. A magyar belügyminiszter egy 1945-ös rendeletével feloszlatta a Nemzeti Casino-t, mint az ország érdekeivel ellentétes múködést kifejtő jogi személyt. Az egyesület alapszabályának értelmében feloszlatása esetén összes vagyonát a Magyar Tudományos Akadémia örökli. Ennek értelmében a Nemzeti Casino könyvtára jelenleg az MTA Könyvtár és Információs Központ gyűjteményének részét képezi. A közel 20.000 könyv feldolgozása sokáig váratott magára, a munka befejezése elött viszont még nem lehet pontos számadatokkal szolgálni. 2015 végéig az állomány körülbelül fele került be az elektronikus katalógusba MARC21 formátumban.

\section{National Casino}

The National Casino Association was founded in 1827 by István Széchenyi. For the nearly 120 years of its existence it was an integral part of the Hungarian public life and culture. The methodically collected and systematized library rose above the country's public libraries qualitatively and quantitatively as well. The Minister of the Interior of Hungary dissolved the National Casino with a decree in 1945 claiming it to be a legal person with an activity against the interests of the country. The association's statutes provide that the Hungarian Academy of Sciences inherits all the assets of the Casino in case of dissolution. Therefore now the library of the National Casino is a collection of the Library and Information Centre of the Hungarian Academy of Sciences. Much time elapsed before the entering the ca. 20.000 books in the calalogue had started, and before the end of the work we don't even know the exact number of the documents. Until the end of 2015 about half of the collection has been introduced into the Aleph electronic catalogue in MARC21 format.

GYURICZA ANDREA

fiatal kutató

MTA Könyvtár és Információs Központ 